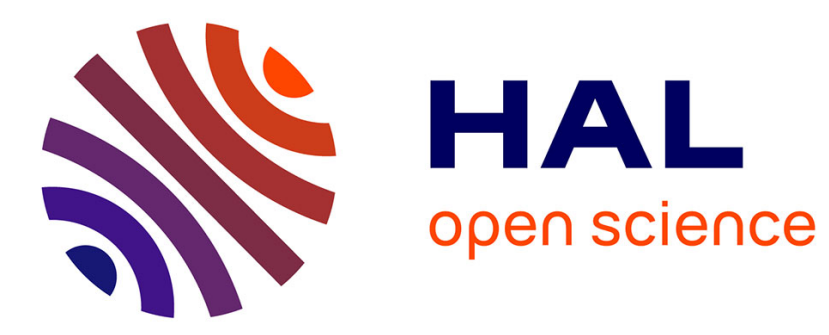

\title{
Water planning to achieve the Sustainable Development Goals Jon Marco Church
}

\section{To cite this version:}

Jon Marco Church. Water planning to achieve the Sustainable Development Goals. Clean Water and Sanitation, Springer International Publishing, pp.1-13, 2021, Encyclopedia of the UN Sustainable Development Goals, 10.1007/978-3-319-70061-8_114-1 . hal-03438364

\section{HAL Id: hal-03438364 https://hal.science/hal-03438364}

Submitted on 21 Nov 2021

HAL is a multi-disciplinary open access archive for the deposit and dissemination of scientific research documents, whether they are published or not. The documents may come from teaching and research institutions in France or abroad, or from public or private research centers.
L'archive ouverte pluridisciplinaire HAL, est destinée au dépôt et à la diffusion de documents scientifiques de niveau recherche, publiés ou non, émanant des établissements d'enseignement et de recherche français ou étrangers, des laboratoires publics ou privés. 
Water Planning to Achieve the Sustainable Development Goals

Jon Marco Church

HABITER Research Laboratory, University of Reims Champagne-Ardenne, Reims, France

This draft article was revised based on the comments received by from the deputy editor, the suggested edits by Ms. Sivadharshini Anandanarayana and resubmitted for publication in Encyclopedia of the UN Sustainable Development Goals, edited by Walter Leal Filho and to be published by Springer. Please do not quote without the explicit permission of the author.

\section{Synonyms}

Integrated Water Resources Management Program; National Plan for Water Resources Protection and Conservation; National Water Strategy; River Basin Plan; Water Plan; Water Planning; Water Sector Reform Program

\section{Definitions}

Water plans are policy instruments with varying degrees of legal bindingness to guide future use, development, and protection of water resources (Werdiningtyas et al. 2020). They can also be considered boundary objects that are co-produced by relevant authorities, experts, and water users and other stakeholders (Graversgaard et al. 2017).

Water planning is the process by which the use, development, and protection of water resources over time is anticipated to prevent conflict over water use, as well as water scarcity and depletion (Loucks et al. 2017). It may or may not lead to a water plan.

\section{Introduction}

All countries engage in one way or the other in water planning. Forms of water planning have existed at least since the first irrigation and urban water supply schemes that appeared thousands of years ago (Grafton and Hussey 2011; Helweg 1985; Loucks et al. 2017; Parker and PenningRowsel 1981). In the United States, water planning has been a responsibility of the United States Army Corps of Engineers since 1850 and the first water plans as standalone documents appeared during the second half of the nineteenth century. Kinds of water plans differ from one country to the other. Not all countries require the development of standalone water plans or of certain kinds of water plans. For instance, countries that rarely suffer from droughts are unlikely to develop plans to deal with water scarcity. A certain variability within countries can also be observed, as not all regions face the same challenges. For example, coastal areas may face infiltration of salted water 
in groundwater aquifers, while other areas may not. Central governments sometimes leave the development of certain kinds of plans to the discretion of local authorities, assuming sufficient capacity is present on the ground. To assist local authorities in the development of water plans, central governments and national agencies may produce guidelines, which play an important role for the harmonization of plans; likewise, to assist developing countries, international organizations such as the United Nations, international financial institutions, such as the World Bank, and other development partners also develop guidelines for the development of different kinds of water plans. Experts and consulting firms also play an essential role in the circulation of planning practices at all levels (Edelenbos et al. 2011).

At the international level, countries are under no legal requirement to produce water plans, also in case of transboundary basins. The only exception is the 2000 EU Water Framework Directive, which requires European Union Member States to develop River Basin Management Plans for each river basin and review them on a six-year basis (De Stefano and Hernández-Mora 2012). Under the 1992 United Nations Economic Commission for Europe (UNECE) Convention on the Protection and Use of Transboundary Watercourses and International Lakes (Helsinki Convention) and other similar arrangements, parties are encouraged to create joint commissions and develop joint plans for transboundary waters (UNECE 2009). The principles of international law, including those contained in the Helsinki Convention, in the 1997 United Nations Convention on the Law of Non-Navigational Uses of International Watercourses (New York Convention) and the 2008 Articles on Law of Transboundary Aquifers, guide riparian countries, which can be located upstream or downstream, to agree on mutually beneficial solutions to shared water problems. Water planning in transboundary contexts is an important tool for preventive diplomacy to reduce the risk of future water use conflicts (Wolf 2007).

\section{Water Planning and Sustainable Development Goals}

\section{From the Agenda 21 to the 2030 Agenda for Sustainable Development}

For decades, global development agendas supported the emergence of water planning as a norm, encouraging the development of certain kinds of plans. For instance, the 1992 Agenda 21 suggested the preparation of plans for various kinds of water uses at different levels. Moreover, the Plan of Implementation of the 2002 World Summit on Sustainable Development stressed the need for integrated water resources management (IWRM) (Matondo 2002) and water efficiency plans, as well as for strategies, plans, and programs at the river basin, watershed, and groundwater level. These commitments were reaffirmed by the 2012 Rio+20 Outcome Document "The Future We Want." Even if the 2030 Agenda for Sustainable Development has no direct SDG target on water planning, water planning is a key component of target 6.5 on the implementation of IWRM at all levels. Water planning and plans are taken into consideration in the definition of both indicator 6.5.1 on integrated water resources management, whose custodian is the United Nations Environment Programme (UN Environment), and indicator 6.5.2 on transboundary basin area with water cooperation, whose custodians are the UNECE and the United Nations Education, Scientific and Cultural Organization (UNESCO). In the latter case, water cooperation is measured in terms of the existence of "operational arrangements," which include water agreements, plans, commissions, and other processes and excludes tools that are not in force or dormant (UN-Water 2018).

\section{The Role of Water Planning to Achieve SDG Targets}

Water planning is a useful instrument to ensure the achievement of SDG 6 and other water-related goals and targets at the national, basin, and local level (Church 2018). By identifying necessary and sufficient measures meant to solve the main problems to achieve water-related SDGs, water 
planning contributes to the optimization of government action, such as the rationalization of human resources and expenditure allocation, for both investment and operation and maintenance. When water-related targets are clear, such as target 6.1 to achieve universal and equitable access to safe and affordable drinking water for all or other nationally appropriate targets, this can sometimes be done through backcasting, where the long-term targets can be broken down into short-term and mid-term intermediary targets and milestones (Kanie and Biermann 2017). Water planning may also allow prioritizing areas and sectors that are in most need and that may accelerate the achievement of SDGs. This is important to make sure that no one is left behind, in accordance to the 2030 Agenda for Sustainable Development. Water planning may also allow for burden sharing at the basin and local level. For instance, in a given country, a certain basin or city may be farther from an SDG target than others; in this case, this basin or city may be requested to make more efforts than others, which may have already done particular efforts in the past. Water planning can help develop and implement burden sharing (Covert 2017).

\section{Using SDG Indicators for Water Planning}

The SDG monitoring framework is also useful for water planning, particularly at the national level. To monitor the implementation of the SDGs and the achievement of water-related targets, the United Nations developed a set of indicators at the national level, and many of its agencies and programs are involved in collecting them (Groves et al. 2015). The United Nations Development Programme (UNDP) helped several developing countries with the production of integrated assessments of SDG readiness, which include dashboards of SDG indicators. Together with official statistics and other data, these dashboards can be useful to provide the information base that is necessary to ensure that water planning is evidence-based and to monitor the achievement of SDG 6 and other water-related goals and targets (Church 2018). They usually build on official statistics, data available to the United Nations and other policy documents, such as national- level sectorial plans. These dashboards are also useful to identify gaps in the information base and policy documents and eventually decide on proceeding with further data collection and policy development. They are also useful to perform an integrated analysis of water plans and other waterrelated sectorial plans, such as plans on poverty reduction, land reform, industrial development, and environmental protection.

\section{Typology of Water Planning and Plans}

\section{Plan-Oriented Versus Process-Oriented Planning}

Like all kind of planning, water planning can be more plan-oriented or process-oriented (Fig. 1) (Friedmann 1967). This means that water planning can revolve around the design, approval, monitoring, evaluation, and revision of water plans, in which case it can be considered as planoriented. Water planning can also revolve around the participation, communication, advocacy, and transaction practices that take place within national water councils, local water boards, river basin councils, joint waters commissions, and other institutional settings where water-related problems and solutions are discussed, adopted, implemented, and reviewed. In this case, water planning can be considered as process-oriented. Water planning does not always produce water plans intended as standalone documents.

\section{From Strategies, to Programs and Projects}

Water plans can be called in different manners. Plan is the generic term. The most typical alternative titles are vision, blueprint, strategy, master plan, roadmap, and program, from the most

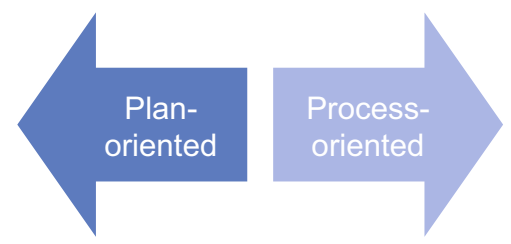

Water Planning to Achieve the Sustainable Development Goals, Fig. 1 The water planning continuum 
concise and generic kind of document to the longest and most specific one. Visions or strategies usually contain a description and analysis of the existing situation, and identify the major problems and set goals that, if achieved, are meant to solve these problems. They may provide some examples of significant measures to achieve these goals, but they do not normally identify all specific measures that are necessary. Strategies and particularly visions are usually more political, as they may include choices that reflect a specific preference for society (Fernandez et al. 2014). Plans and programs tend to be more technical. A master plan or program is more operational and usually contains concrete measures that are supposed to be necessary and sufficient to achieve strategic goals, according to a specific logical framework (Yamaswari et al. 2016). However, the term "program" is often reserved for a set of measures, usually in the form of projects, that are meant to solve one of the major problems identified within a plan. A roadmap normally presents measures, including programs, in a sequential manner. In this case, the assumption is that the timing of measures is particularly important to achieve the expected results. River contracts are a specific kind of plan, where main water users and other key stakeholders agree to take specific responsibilities and implement concrete measures, sometimes in exchange of financial compensation.

\section{Types of Water Plans}

There are many specific types of plans dealing with different water-related issues (Fig. 2) (Matondo 2002). At the national, regional, and basin level, there are irrigation and drainage plans, hydropower plans, industrial waters plans, plans on water-related disasters, water quality plans, groundwater plans, estuary plans, and coastal water plans, just to mention the most common ones. There are also generic plans on IWRM or water efficiency that try to deal with water resources in a holistic manner. In recent years, there is a push toward source-to-sea planning to prevent issues of land-based sources of marine pollution (Granit et al. 2017). At the national, regional, district, and local level, there are plans on drinking water supply and sanitation, water safety plans, most plans on water-related disasters such as flooding and draught (Hartmann and Driessen 2017), as well as rainwater plans. These plans are rarely at the basin level, as they focus more on the communities that need drinking water supply and sanitation and that need to be protected from water-related disasters than on water flows.

\section{The Cycle of Water Planning}

\section{Team Building and Problem Framing}

There is no one-size-fits-all in water planning (Ostrom and Cox 2010). However, if one was to identify an ideal-typical cycle of water planning (Fig. 3) (Franks 1998), it would start with building a balanced team and with the framing of the problem-shed. This is usually done by the authority responsible for water management at the relevant level, typically the ministry in charge of water resources at the national level, the river basin authority at the basin level, or the department responsible for water services at the local level. Team-building and problem framing are important, because they introduce a relational and political bias in the process and influence the acceptability and, ultimately, legitimacy of the planning exercise. The teams responsible for water planning are usually called drafting committees, working groups or task forces and they may include one or more lead authors, experts in different water-related issues, technical assistants, as well as support staff.

\section{Plan Development}

Plan development always starts with the establishment of an information base (Fig. 4). This includes the legal and policy framework, a stakeholder analysis, as well as the identification of the geographical scope, time horizon, including a definition of short, medium, and long-term, and relevant sectors. The information base also implies data collection and visualization, particularly in the form of maps and atlases. This may include surveys of expert opinion, particularly of key issues, and public opinion, particularly of 

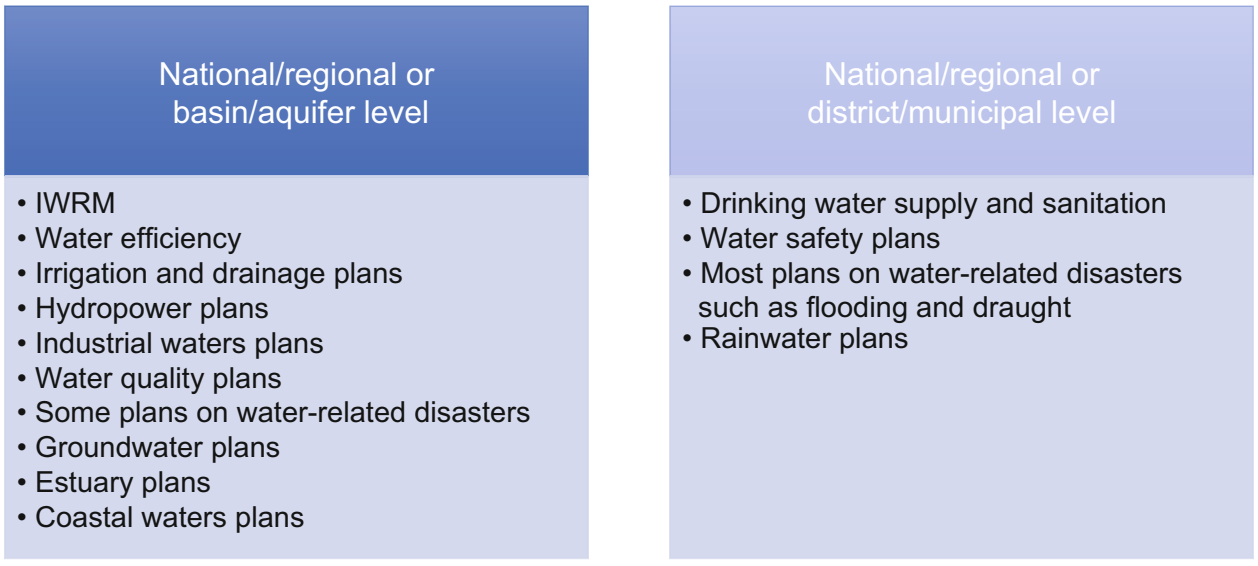

Water Planning to Achieve the Sustainable Development Goals, Fig. 2 Types of issue-specific plans

\section{Water Planning \\ to Achieve \\ the Sustainable \\ Development Goals,}

Fig. 3 The cycle of water planning

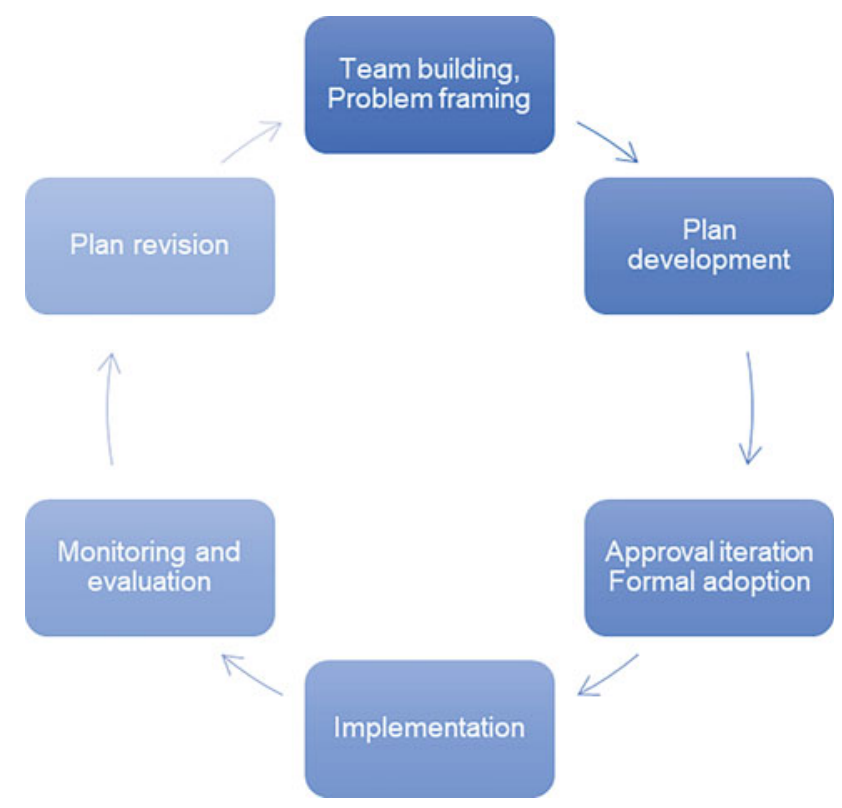

water users. If data is sufficiently reliable and complete, this may allow some modeling and simulations of water flow and quality (Tidwell et al. 2004; Yates et al. 2005a, b; Sahoo et al. 2020). The identification of a tendential scenario, as well as two to four alternative scenarios, may then help to deal with uncertainty (Fernandez et al. 2014; Snover et al. 2003; Straton et al. 2011). These scenarios may be taken from national sources, such as national development strategies or adapted from international sources, such as five stylized scenarios for water resources (Gallopín 2012) or the five shared socioeconomic pathways frequently used in climate-related research (Van Vuuren et al. 2014). Scenarios are important to identify measures that are commensurate with likely future development paths. Plans can be composed of more than one volume.

\section{Diagnostic Analysis}

Diagnostic analysis is the typical next step in water planning. This implies the identification of 


\section{A. Information base}

1. Legal and policy framework

2. Stakeholder analysis

3. Geographical scope, time horizon, relevant sectors

4. Data collection, mapping

5. Public opinion, expert opinion

6. Modeling, simulations

7. Scenarios, uncertainty

B. Diagnostic analysis (problems)

\section{Problems}

2. Causes

C. Goal setting (problem solved)

1. Goals, intermediary goals

2. Targets

D. Implementation measures (solutions)

\section{Regulatory \\ 2. Economic \\ 3. Communication \\ 4. Direct implementation \\ 5. Monitoring and evaluation}

\section{E. Annexes}

1. Data tables, atlas

2. Indicators

3. Timeframe, milestones

4. Financing plan

5. Sustainability assessment

6. Gender assessment

7. Glossary, bibliography

\section{Water Planning to Achieve the Sustainable Develop-} ment Goals, Fig. 4 Typical components of a water plan

major and minor problems that require action from various perspectives, including winners and losers. These issues must then be analyzed based on the information collected. Hypotheses about the direct and indirect causes of these problems can thus be formulated. Diagnostic analysis can benefit from the participation of water users, particularly for the identification of specific issues and potential causes.

\section{Goal Setting}

Goal setting is normally considered the core element of water planning. It implies envisioning the problem solved and eventually intermediary goals. These goals may take the form of targets when they correspond to a specific figure or range. The credibility of these targets depends on the reliability of the information base, sound analysis, as well as trust in the governance system. Goals are strategic in the sense that they indicate an overall direction for water management without detailing how the goals will be achieved or how contingencies will be dealt with. Goals are also political, as they imply tradeoffs between options (Mooney et al. 2012).

\section{Implementation Measures}

Water planning usually extends to the indication of the measures that are expected to achieve goals. These measures shall be sufficient and necessary for that purpose. They include regulation, such as legal instruments and policy guidelines, economic instruments, such as taxes, subsidies, quotas, and exchangeable permits, communication instruments, as well as direct implementation, including both manmade and nature-based solutions. However, solutions are usually a mix of different kinds of measure, which are meant to be complementary and reinforce each other. They may include specific monitoring and evaluation provisions.

\section{Evidence Base and Other Materials}

Water plans usually include many other important elements. Data tables collect the data contained in the plan and other relevant data and maps, which can be compiled into an atlas, showing also the spatial distribution of measures. Indicators are measurable elements that can signal whether a goal or target was achieved or not. In some cases, indicators may coincide with some SDG indicators. Timeframes represent the goals and measures contained in the plan in a chronological manner and may help ensure that goals and measures follow a logical order. They may indicate milestones, which consist in significant goals that are expected to be achieved under the plan, on whose achievement other goals may depend. Because of the SDGs, 2030 is a common time horizon or milestone for many planning exercises. In some cases, water plans and especially programs also include financing plans, presenting 
estimates about the cost of the measures proposed to achieve the stated goals. Water plans may contain various kinds of impact assessments, particularly on cross-cutting issues such as sustainability and gender. Finally, plans may include a glossary of key terms and sometimes a bibliography of key sources.

\section{Approval Iterations}

Once draft plans are completed, they enter approval iteration. At the national level, plans are usually developed under the auspices of one or more government agencies. The first step normally involves consultation with other government agencies through written correspondence and coordination meetings. Parliamentary committees in charge of water and other related issues may also be consulted. The same goes for representatives of local authorities, possibly through their representative assemblies, if they exist. Water plans typically undergo some form of public hearing or at least consultation with water users, possibly through water user associations or federations thereof (Wengert 1971). Consultations normally require several iterations between government, parliament, local authorities, and sometimes water users. These iterations may take months if not years. As soon as the water plan is sufficiently consensual or at least the choices to be made are clear, the plan is adopted by the competent authority Always at the national level, this may be the ministry in charge of water through a ministerial resolution or, more frequently, through a decision of the council of ministers, given the intersectoral nature of water. In this regard, the role of the prime minister and his office can be crucial to ensure interministerial coordination. The process is similar at the basin and at other subnational levels, as well as in transboundary contexts, all differences considered.

\section{Plan Implementation}

The implementation of strategic plans is not mechanic. They sometime require the development of specific programs and action plans that were identified by the plan as priority actions or areas of intervention. These are further planning documents. Contingencies may also emerge that require adaptation to or deviation from the water plan through tactical measures that were not foreseen by the plan, such in the case of a major budgetary crisis or water-related disaster. For this reason, plans or the decisions that adopt plans may establish implementation units that are responsible for the daily follow-up to the plan. National, regional, or basin-level water councils may also contribute to the process of constant revision and adaptation of the plan by increasing the number of stakeholders involved, giving them a voice. Without such institutional arrangements, water plans often remain a paper in a drawer that may represent a learning experience for those who contributed to its preparation, but with limited impact beyond them and perhaps those around them. This can also happen willingly, for example if a government considers that measures contained in the water plan are not applicable.

\section{Monitoring and Evaluation}

Plans require regular monitoring and evaluation, as well as revisions. The plan can appoint a responsible entity for the monitoring and the evaluation of the implementation of the plan. It is advisable that this is not the plan implementation unit itself, because of conflict of interest. It may be another government agency, an external observatory, or an audit service. However, a wellfunctioning institutional setup with an active water council may be preferable, because of greater transparency and responsiveness. External monitoring and evaluation may in fact be bureaucratic and untimely. Water plans usually provide a clear time horizon, after which a plan is expected to be revised, such as every 5,10 , or 20 years. This may also be the case vis-à-vis some significant changes to the situation on the ground. Plans may contribute to the design of institutional setups that constantly update the information and knowledge base for water planning, that are capable to seize opportunities for water development, take preventive measures against future threats through risk reduction, and react in case of significant changes and water-related disasters. As such, water planning can be a contribution to achieve so-called adaptive governance (Groves et al. 2015). 


\section{The Relationship between Water Plans and Other Documents}

\section{Hierarchical Principles}

The relationship between water plans among themselves and among other legal and policy documents, such as spatial plans (Hurlimann and Wilson 2018; Woltjer and Al 2007), can be complicated (Figs. 5 and 6) (Hamman 2020). In case of inconsistency, which one prevails? Water plans usually have a low level of legal bindingness. As such, they are more policy documents than legal ones. Like for many policy documents, the exact relationship among plans may be undetermined, leaving it up to policymakers and in some cases courts to use them or not. In some planning systems, the relationship among planning documents may be such that lower level plans prevail over higher level ones, based on the principle of specificity. This bottom-up approach is more likely to be found in decentralized political systems. The opposite can also be found, meaning that higher level plans may trump lower level ones. This top-down approach is more typical of centralized systems. A hybrid option is that lower level plans need to wait for the approval of higher level plans and then must take them into consideration, but not necessarily conform. Another similar hybrid solution is that lower level plans need to be submitted to higher level authorities for consideration, usually within a specific timeframe, without being required to follow the advice received. Uncoordinated and hybrid approaches are quite common.

\section{The Key Role of Permits for Plan Effectiveness}

Permits for special water use and building permits play a key role in ensuring the effectiveness of water plans and planning processes. Special uses of water are typically subject to the request of permits, sometimes also in the context of building permits. In the legislation, the issuance of permits may be subject to conformity not only with the laws in force but also with water plans and other planning documents. In many cases, plans are at least taken into consideration by public authorities for the issuance of permits. Permits can also be subject to appeal in court both from other public authorities, which may challenge the legal grounds of the decision to issue or not permits, and, provided sufficient publicity is given to issued permits and to the issuing process, also from other users, neighbors, and interested parties. Moreover, permits play a key role for the monitoring of the use of water resources and are a key component of water information systems and knowledge bases.

\section{Public Participation in Water Planning}

\section{Participation in Water Decision-Making}

Like in other planning and environmental domains, public participation in water-related planning and decision-making is important, just as it is for all other environmental issue, as per the 1997 UNECE Convention on Access to Information, Public Participation in Decision-making and Access to Justice in Environmental Matters (Aarhus Convention). It enlarges the knowledge base, includes the perspectives of those who are usually left behind, particularly minorities and the poor, and prevents conflicts of use. It is also a key component of IWRM, including in its gender dimension. However, public participation in planning, including water planning, has been object of scrutiny and some criticism for decades (Wengert 1971). The main issue is representation of interests and stakeholders. Areas covered by water systems are often large with a high number of inhabitants and stakeholders with sometimes divergent actual and perceived interests. How to make sure that they are and feel represented? Intermediary organizations, such as water user associations and non-governmental organizations play an important role in this regard, as elected officials are usually the expression of a majority of the population and do not always fully represent minority interests. Therefore, the national, regional, basin, and district level participation is usually indirect. Direct participation is normally effective only in small communities. There is evidence showing that public participation may improve the quality of water planning (Graversgaard et al. 2017). Most forms of public 


\section{Water Planning to Achieve the Sustainable Development Goals,}

Fig. 5 Typology of relationship between waterrelated plans

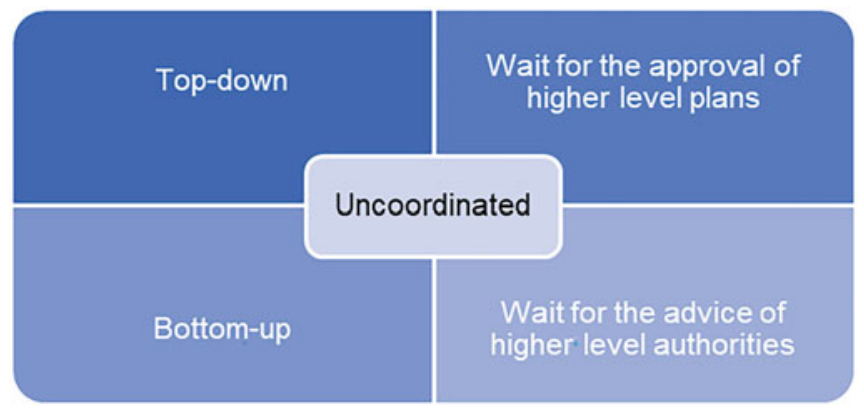

participation increase the duration of planning processes and lead to necessary tradeoffs among different interests (Mooney et al. 2012).

\section{Co-Production of Water Planning}

Co-production of water planning usually takes place between policymakers and experts. Larger companies, such as water service providers, large NGOs, and water user associations, may also be involved in this process. It is normally recommended to consult and elicit the opinion of the general population, smaller companies, and grassroots NGOs through interviews and household surveys. It is important to keep the population informed of existing problems and potential solutions through appropriate means of communication. Examples include local newspapers, brochures, posters, local radio stations, and social media. It is also important to ensure as much access as possible to water-related information.

\section{Challenges to Water Planning}

\section{Process: What Observation, Scale and Effectiveness?}

First of all, there is no global or regional repository, observatory, or documentation center of basin plans and planning. Many plans, particularly those at the national level, are increasingly available online. The existence at least of a repository would help better understand the phenomenon and encourage comparative analysis. Second, it is difficult to assess the effectiveness of water planning. Planning has been oftentimes criticized as ineffective, in the sense that plans are rarely followed to the letter (Millard-Ball 2013). This phenomenon is typical of policy documents that, unlike legal ones, are meant to guide action in a certain direction more than to enact specific rules or other measures. Planning processes are also opportunities for key stakeholders to communicate about strategic priorities on water resources, which is already an outcome per se, regardless of whether they lead to a planning document or not and whether this document is respected or not. Another frequent issue is the definition of the scope of water planning: some basins or cities can be too big for a single water plan, others can be too small. Moreover, basins, just like settlements, can always be assembled into larger units and broken down into smaller ones.

\section{Integration: How Far to Go?}

On the content side, the major challenge is currently integration. First, the integration of adaptation to climate change into water plans (Gober 2013; Gober et al. 2010; Grafton et al. 2014; Hurlimann and Wilson 2018; White et al. 2006) and, in general, the issue of adaptive planning (Groves et al. 2015), meaning the capacity of planning to anticipate change in a context of uncertainty. The role of science and other kinds of knowledge in water planning is important to increase the resilience of water systems. Second, the integration of so-called blue, gray, and green water in water planning. This includes the reduction, recycle and reuse of industrial sewage in a context of circular economy and the water absorbed by soil, trees and other kinds of vegetation for rainwater management (Falkenmark and Rockström 2006; Woltjer and Al 2007). Third, the integration of water planning from source to sea, including groundwater. This is important in 


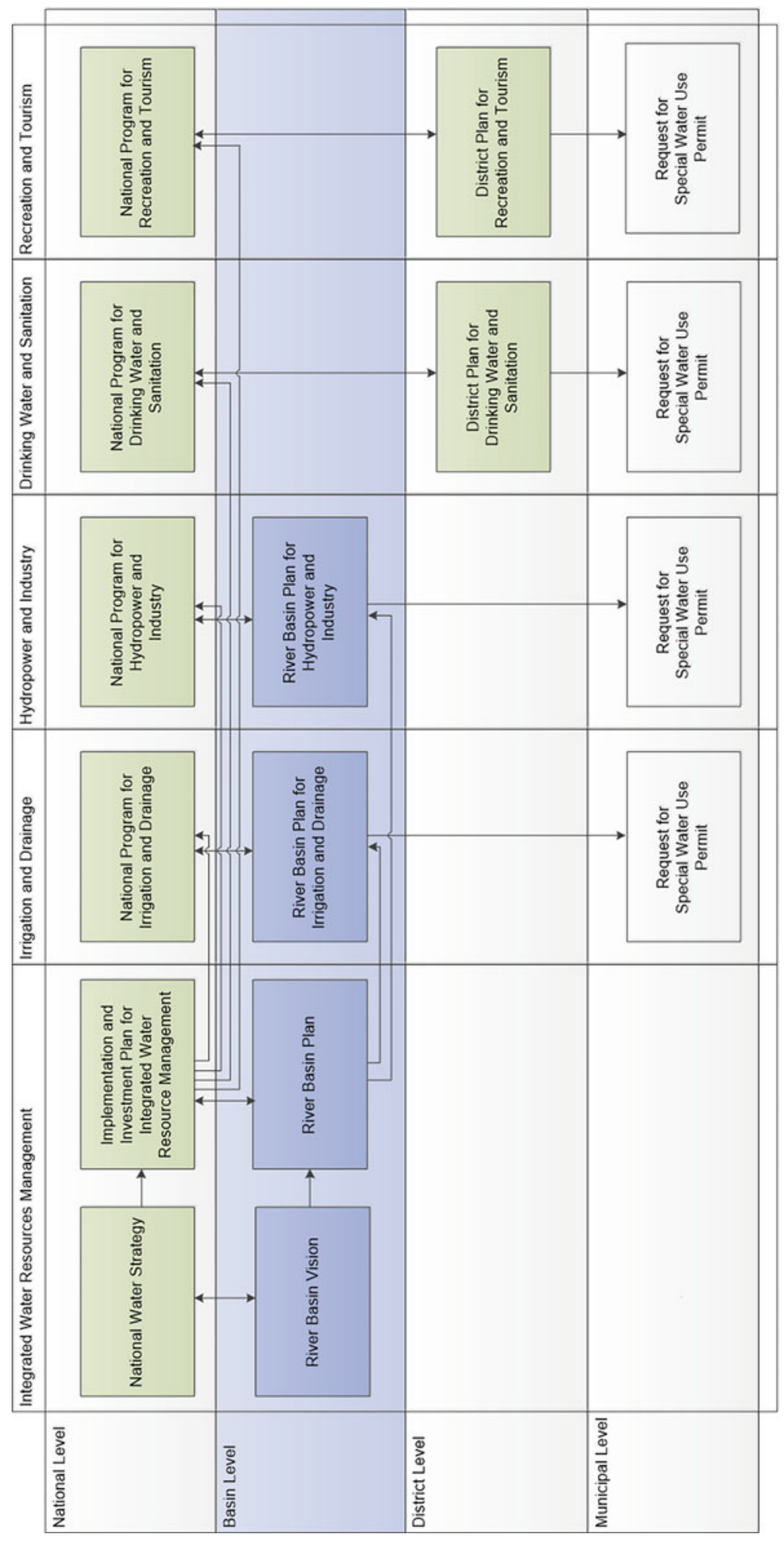

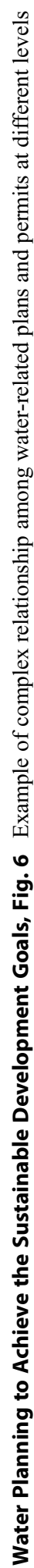


coastal areas for the prevention of marine pollution from land-based sources and to deal with issues such as the infiltration of seawater into freshwater water bodies both on the surface and under the ground.

\section{Knowledge: What Role for Science, Technology, and Society?}

Finally, the role of science, expertise, and other kinds of knowledge, such as traditional and indigenous knowledge, but also everyday knowledge, needs to be further explored, particularly in its interaction with policymaking. Water management is often considered as a highly technical issue that is normally better dealt with by water engineers and other specialists. However, water planning is often political, as it implies prioritizing certain actions and their beneficiaries over others, sometimes leaving some parts of the population behind. To help reduce the knowledge gap between science and policymaking and also to depoliticize some choices, decision-support systems were developed based on more or less sophisticated modeling of water flows and human behavior, such as SWAT, AQUATOOL, and WEAP (Andreu et al. 1996; Loucks and Costa 1991). More recently, the diffusion of networked metering systems and the emergence of automatic canals and other water-related systems, potentially supported by machine learning and other "smart water" solutions, is automatizing many routine management decisions (Stewart et al. 2010). This has a potential impact on water planning in both cities and basins, including transboundary areas, as it extends the knowledge base and reduces potentially conflictual water management decisions, removing the human agency behind. At the same time, it crystalizes existing settings and routines in nonhuman systems, perhaps blurring the embedded political choices behind.

\section{Cross-References}

- Implementing Water, Energy, and Food Sustainable Development Goals

- Integrated Water Resource Management
- Urban Water Infrastructure

- Water and Adaptation to Climate Change

- Water Balance

- Water Cycle

- Water Governance

- Water Management and Management Actions

Water Monitoring

Water Security

\section{References}

Andreu J, Capilla J, Sanchís E (1996) AQUATOOL, a generalized decision-support system for waterresources planning and operational management. $\mathrm{J}$ Hydrol 177:269-291. https://doi.org/10.1016/00221694(95)02963-X

Church JM (2018) Integrating the sustainable development goals and the national development strategy into the national water strategy of Tajikistan: a methodological proposal. In: Актуальные проблемы современного общества и пути их решения в условиях перехода к цифровой экономике: материалы XIV Международной научной конференции. Moscow Witte University, Moscow, pp 11-26

Covert J (2017) Planning for the implementation of SDG-14. Environ Policy Law 47:6-8. https://doi.org/ 10.3233/EPL-170003

De Stefano L, Hernández-Mora N (2012) Water planning and management after the EU water framework directive. In: De Stefano L, Llamas M (eds) Water, agriculture and the environment in Spain: can we square the circle? CRC Press, London, pp 35-44

Edelenbos J, van Buuren A, van Schie N (2011) Co-producing knowledge: joint knowledge production between experts, bureaucrats and stakeholders in Dutch water management projects. Environ Sci Pol 14(6): 675-684. https://doi.org/10.1016/j.envsci.2011.04.004

Falkenmark M, Rockström J (2006) The new blue and green water paradigm: breaking new ground for water resources planning and management. J Water Resour Plan Manag 132:129-132. https://doi.org/10.1061/ (ASCE)0733-9496(2006)132:3(129)

Fernandez S, Bouleau G, Treyer S (2014) Bringing politics back into water planning scenarios in Europe. J Hydrol 518:17-27. https://doi.org/10.1016/j.jhydrol.2014.01. 010

Franks T (1998) Water and the project cycle. Waterlines 16 (4):5-7

Friedmann J (1967) A conceptual model for the analysis of planning behavior. Adm Sci Q 12(2):225-252. https:// doi.org/10.2307/2391550

Gallopín GC (2012) Five stylized scenarios. UNESCO, Paris

Gober P (2013) Getting outside the water box: the need for new approaches to water planning and policy. Water 
Resour Manag 27:955-957. https://doi.org/10.1007/ s11269-012-0222-y

Gober P, Kirkwood CW, Balling RC, Ellis AW, Deitrick S (2010) Water planning under climatic uncertainty in Phoenix: why we need a new paradigm. Ann Assoc Am Geogr 100:356-372. https://doi.org/10.1080/ 00045601003595420

Grafton RQ, Hussey K (eds) (2011) Water resources planning and management. Cambridge University Press, Cambridge

Grafton RQ, Pittock J, Williams J, Jiang Q, Possingham H, Quiggin J (2014) Water planning and hydro-climatic change in the Murray-Darling basin, Australia. Ambio 43:1082-1092. https://doi.org/10.1007/s13280-0140495-X

Granit J, Liss Lymer B, Olsen S, Tengberg A, Nõmmann S, Clausen TJ (2017) A conceptual framework for governing and managing key flows in a source-to-sea continuum. Water Policy 19(4):673-691. https://doi. org/10.2166/wp.2017.126

Graversgaard M, Jacobsen B, Kjeldsen C, Dalgaard T (2017) Stakeholder engagement and knowledge co-creation in water planning: can public participation increase cost-effectiveness? Water 9:191. https://doi. org/10.3390/w9030191

Groves DG, Bloom E, Lempert RJ, Fischbach JR, Nevills J, Goshi B (2015) Developing key indicators for adaptive water planning. J Water Resour Plan Manag 141. https://doi.org/10.1061/(ASCE)WR. 1943-5452.0000471

Hamman P (2020) Sustainability governance and hierarchy. Routledge studies in sustainability. Routledge, New York

Hartmann T, Driessen P (2017) The flood risk management plan: towards spatial water governance. J Flood Risk Manag 10:145-154. https://doi.org/10.1111/jfr3. 12077

Helweg OJ (1985) Water resources: planning and management. Wiley, New York

Hurlimann A, Wilson E (2018) Sustainable urban water management under a changing climate: the role of spatial planning. Water 10:546-568. https://doi.org/ 10.3390/w10050546

Kanie N, Biermann F (eds) (2017) Governance through goals: new strategies for global sustainability. MIT Press, Cambridge, MA

Loucks DP, Costa JR (eds) (1991) Decision support systems: water resources planning. Springer, Berlin

Loucks DP, Ev B, Stedinger JR, Dijkman JPM, Villars MT (eds) (2017) Water resources systems planning and management: an introduction to methods, models and applications, 2nd edn. UNESCO, Paris. https://doi.org/ 10.1007/978-3-319-44234-1

Matondo JI (2002) A comparison between conventional and integrated water resources planning and management. Phys Chem Earth 27:831-838. https://doi.org/ 10.1016/S1474-7065(02)00072-4
Millard-Ball A (2013) The limits to planning: causal impacts of city climate action plans. J Plan Educ Res 33:5-19. https://doi.org/10.1177/0739456x12449742

Mooney C, Baldwin C, Tan P-L, Mackenzie J (2012) Transparency and trade-offs in water planning. $\mathrm{J}$ Hydrol 474:66-73. https://doi.org/10.1016/j.jhydrol. 2012.06.040

Ostrom E, Cox ME (2010) Moving beyond panaceas: a multi-tiered diagnostic approach for social-ecological analysis. Environ Conserv 37(4):451-463. https://doi. org/10.1017/S0376892910000834

Parker DJ, Penning-Rowsel EC (eds) (1981) Water planning in Britain. Allen and Unwin, Hemel Hempstead

Sahoo S, Dhar A, Debsarkar A, Pradhan B, Alamri AM (2020) Future water use planning by water evaluation and planning system model. Water Resour Manag 34 (15):4649-4664. https://doi.org/10.1007/s11269-02002680-8

Snover AK, Hamlet AF, Lettenmaier DP (2003) Climatechange scenarios for water planning studies: pilot applications in the Pacific northwest. Bull Am Meteorol Soc 84:1513-1518. https://doi.org/10.1175/ BAMS-84-11-1513

Stewart RA, Willis R, Giurco D, Panuwatwanich K, Capati G (2010) Web-based knowledge management system: linking smart metering to the future of urban water planning. Aust Plan 47:66-74. https://doi.org/10. 1080/07293681003767769

Straton AT, Jackson S, Marinoni O, Proctor W, Woodward E (2011) Exploring and evaluating scenarios for a river catchment in northern Australia using scenario development, multi-criteria analysis and a deliberative process as a tool for water planning. Water Resour Manag 25:141-164. https://doi.org/10.1007/s11269-0109691-z

Tidwell VC, Passell HD, Conrad SH, Thomas RP (2004) System dynamics modeling for community-based water planning: application to the middle Rio Grande. Aquat Sci 66:357-372. https://doi.org/10.1007/ s00027-004-0722-9

UNECE (2009) River basin commissions and other institutions for transboundary water cooperation. United Nations, Geneva

UN-Water (2018) SDG 6 synthesis report 2018 on water and sanitation. United Nations, New York

Van Vuuren DP et al (2014) A new scenario framework for climate change research: scenario matrix architecture. Clim Chang 122:373-386. https://doi.org/10.1007/ s10584-013-0906-1

Wengert N (1971) Public participation in water planning: a critique of theory, doctrine, and practice. J Am Water Resour Assoc 7:26-32. https://doi.org/10.1111/j.17521688.1971.tb01675.x

Werdiningtyas R, Wei Y, Western AW (2020) The evolution of policy instruments used in water, land and environmental governances in Victoria, Australia from 1860-2016. Environ Sci Pol 112:348-360. https://doi.org/10.1016/j.envsci.2020.06.012 
White KD, Vaddey SV, Hamlet AF, Cohen S, Neilsen D, Taylor W (2006) Integrating climate impacts in water resource planning and management. Paper presented at the 13th international conference on cold regions engineering, Orono, ME, July 23-26

Wolf AT (2007) Shared waters: conflict and cooperation. Annu Rev Environ Resour 32:241-269. https://doi.org/ 10.1146/annurev.energy.32.041006.101434

Woltjer J, Al N (2007) Integrating water management and spatial planning. J Am Plan Assoc 73:211-222. https:// doi.org/10.1080/01944360708976154

Yamaswari IAC, Kazbekov J, Lautze J, Wegerich K (2016) Sleeping with the enemy? Capturing internal risks in the logical framework of a water management project. Int J Water Resour Dev 32(1):116-134. https://doi.org/ 10.1080/07900627.2015.1058766

Yates D, Purkey D, Sieber J, Huber-Lee A, Galbraith H (2005a) WEAP21 - a demand-, priority-, and preference-driven water planning model (part 2: aiding freshwater ecosystem service evaluation). Water Int 30: 501-512. https://doi.org/10.1080/02508060508691894

Yates D, Sieber J, Purkey D, Huber-Lee A (2005b) WEAP21 - a demand-, priority-, and preference-driven water planning model (part 1: model characteristics). Water Int 30:487-500. https://doi.org/10.1080/ 02508060508691893 